\title{
Human resources in the global higher education market: the presence of foreign professors in Spanish universities
}

\author{
Manuel Pereira-Puga \\ INSTITUTO DE POLÍTICAS Y BIENES PÚBLICOS (IPP) - CSIC \\ manuel.pereiralacsic.es \\ Received: 03/01/2017 \\ Accepted: 20/03/2017
}

\begin{abstract}
Despite the existence of a global higher education market in which universities compete to attract talented academics from all over the world, most higher education institutions hire very few foreign researchers. Indeed, in Spain, only 1 in 40 academics are from abroad. This article focuses the Spanish case in order to deepen our understanding of the factors affecting the internationalisation of academic staff in the higher education sector. The analysis is based on data from the European Register of Tertiary Education Institutions and Spanish Higher Education Statistics data, collected by Spain's National Statistics Office. The main results of this exploratory analysis show that there are differences between Spanish regions in terms of the proportion of foreign staff they hire. Moreover, at the institutional level, the most internationalised universities are relatively new institutions, and most of them are located in Catalonia. The political and economic framework in Spain discourages the hiring of international academics. However, in this context, two important insights should be highlighted: On the one hand, the differences between Catalonia and the rest of the Spanish autonomous communities show that sub-national policies may have a strong impact on internationalisation processes in decentralised countries like Spain; on the other hand, divergence between universities shows the importance of the strategic behaviour of actors facing environmental pressures.
\end{abstract}

Keywords: higher education, academic profession, academic careers, organisational change, internationalisation.

Corresponding author: Manuel Pereira-Puga, Instituto de Políticas y Bienes Públicos (IPP) - CSIC. C/ Albasanz, 26-28, 28037 Madrid.

Suggested citation: Pereira-Puga, M. (2017). Human resources in the global higher education market: the presence of foreign professors in Spanish universities. Debats. Journal on Culture, Power and Society, 2, 125-139. doi: http://dx.doi.org/10.28939/ iam.debats-en.2017-10

\section{INTRODUCTION}

Universities play an important role in the creation and dissemination of knowledge and over the last few decades, higher education institutions (HEIs) have become crucial in the generation of economic growth and social wellbeing in both developed and developing countries. In 1996, the Organization for Economic Cooperation and Development (OECD) coined the concept 'Knowledge-based economy' (OECD, 1996). This term refers to a type of productive system where the creation, organisation, and transfer of knowledge are key for economic success. Implementation of this model requires a range of conditions, including: allocation of a significant share of gross domestic product (GDP) to research and development (R\&D) activities, establishment of R\&D funding programs 
(e.g. Horizon 2020), creation of innovation-based companies, proliferation of innovators and entrepreneurs, and training of a large number of highly skilled workers who are willing to learn over the course of their lifetime (lifelong learners), among other factors.

In this context, universities are being put under increasing pressure to improve the outcomes of their main objectives: training future professionals (teaching-learning), knowledge creation (research), and knowledge transfer (patents, public-private collaborations, start-ups, etc.). Examples of this are the implementation of performance-based funding systems (Jongbloed and Vossensteyn, 2001; Liefner, 2003; McLendon and Hearn, 2013) and the growing competence among universities to attract students and academics (Mazzarol and Soutar, 2001; Altbach et al. 2009; Pereira-Puga, 2014; 2015), as well as the growing importance of achieving a high placement on university rankings (Salmi, 2009; Hazelkorn, 2011; Wang et al., 2013; Enders, 2014), meaning that national governments now compete with each other to get their HEIs ranked as high as possible.

The higher education sector has changed a lot over the past 30-40 years and one of the most important changes is academic internationalisation (Scott, 1998; Altbach and Teichler, 2001; De Wit, 2002; Enders, 2004; Mazzarol and Soutar, 2012; Altbach, 2015). In this sense, internationalisation refers to a wide range of policies and strategies implemented by governments and universities and is aimed at attracting more foreign students, academics, and research funds from supranational bodies, as well as improving institutional performance in terms of international publications and collaborations with foreign institutions, among other factors (Altbach, 2015, p. 6).

Focusing on the internationalisation of human resources, it must be noted that academic mobility has a long tradition which commenced in the Middle Ages (Musselin, 2004; Byram and Dervin, 2009; Kim and Locke, 2010; Bauder, 2015). However, encouraging international mobility among academic staff only more recently became a goal for HEIs (De Wit, 2002).
Within the European Union (EU), several public policies implemented relatively recently have aimed to promote international mobility (Musselin, 2004, p. 56). For example, the Marie Skłodowska-Curie Program for postdoctoral mobility. Nevertheless, most of the national labour markets still remain local and just a few countries and institutions dominate the 'global scientific systems' in terms of attracting foreign professors and researchers (Altbach, 2015, p. 6).

Taking into account that human resources policies in academia are a strategic element of knowledge production (Bauder, 2015), it is important to deepen our understanding of the factors underlying the differences between universities in terms of the outputs of their hiring models. As we know, the hiring processes carried out by HEIs are affected by factors such as their level of autonomy from the state (Olsen, 2007; Dobbins and Knill, 2009; Whitley, 2012), existing laws (Bosch, 2006; Cruz-Castro and Sanz-Menéndez, 2015), and cuts in public budgets (Griffith, 1993). Given these constraints, insight can be gained from analysing how and why universities located in the same country (and thus, with a similar degree of autonomy from the state, a common regulatory framework, and the same funding system), significantly differ in terms of their levels of academic staff internationalisation.

This current article describes an exploratory analysis of the internationalisation of the 48 Spanish public universities with the objective of analysing differences in terms of their share of international academic staff, both at the regional and the university level. This should deepen our understating of the factors affecting the internationalisation of human resources in academia. Moreover, the Spanish case is especially relevant for two reasons: Firstly, the university landscape in Spain is very diverse, e.g. consolidated universities coexist alongside several HEIs which are less than thirty years old, thus allowing the different types of environmental adaptation patterns adopted by these diverse institutions to be explored. Secondly, Spanish universities largely depend on regional rather than central government funding, meaning that the effects of different policies on hiring-process outcomes can be examined. 
This article is structured as follows: The first section contains the theoretical framework guiding the analysis, the second section describes the most relevant characteristics of Spanish HEIs and their implications in university hiring processes, the third section presents the data and ratio calculation methods, the fourth section analyses the results and discusses their implications for the future of the higher education sector in Spain, and the final section provides some conclusions.

\section{THEORETICAL FRAMEWORK}

The political and economic environments have changed dramatically over the last four decades and as a result, universities have developed many different types of institutional responses. In this regard, more than twenty years ago Clark Kerr (1993) stated that the changes taking place in universities are more revolutionary than evolutionary. The changing world has produced major transformations in the institutional management of universities as well as in the nature of the higher education industrial sector (Peterson, 2007). One of the major changes was the creation of a global higher education market in which universities are expected to attract and retain the best international students and academics. This situation is consistent with the dynamics of other knowledge-intensive sectors where the attraction of outstanding workers is a strategic aspect of the competition between companies (Grant, 1996). Indeed, the OECD (2008) dedicated a full report to the international mobility of highly-skilled workers. In this respect, it is interesting to note that some of the most important university rankings, such as that in the Times Higher Education (THE) ${ }^{\mathbf{1}}$ supplement, include the percentage of international academic staff as one of its indicators.

However, the global higher education market involves just a small group of countries and universities, while in contrast, most national academic labour markets

1 The methodology of the THE World University Ranking can be found here: https://www.timeshighereducation.com/ news/ranking-methodology-2016 remain local (Altbach, 2015). Thus, it is important to understand why some universities attract significant numbers of international professors while others still have large proportions of national staff and 'inbred' academics (Godechot and Louvet, 2008; Sivak and Yudkevich, 2009; Yudkevich et al., 2015). Notably, organisational behaviour is the product of external pressures exerted by environmental actors, additional constraints (such as normative frameworks), and organisations' active responses to change or stability (Pfeffer, 1982; Oliver, 1991; Gornitzka, 1999). In other words, there are factors affecting universities that are not managed by universities themselves (e.g. the existing labour laws and the country's economic development). Nonetheless, universities play an active role in other aspects of their management, such as their organisational response to environmental demands.

The literature on higher education argues that one of the key variables determining organisational behaviour is autonomy from the state. Indeed, Whitley (2012) classifies universities based on their degree of autonomy, from more to less autonomous, as: Private-portfolio, State-chartered, State-concentrated, and Hollow. Highly autonomous universities are free to establish their own hiring and promotion processes and to negotiate salaries and benefits, etc., while there is less room for manoeuvre in more dependent institutions. Therefore, one would expect to find very dissimilar hiring decisions in countries with a high degree of university autonomy and, on the contrary, more homogenous hiring and promotion processes in HEIs in countries with very state-dependent universities. Another relevant factor explaining international academic mobility is the attractiveness of the country, and this significantly effects the appeal of institutions. Indeed, Lepori et al. (2015) recently found that factors linked to universities' home country play an even more important role in academics' choices than the quality of the university itself. This connects with research on international migration suggesting that the characteristics of the destination country are good predictors of migration decision-making (De Jong and Fawcett, 1981; Ritsilä and Ovaskainen, 2001). 
The aforementioned factors directly influence the hiring-process outcomes and are beyond universities' capacity to intervene. However, HEIs are still active rather than passive actors; they can respond to their external constraints in different ways. In her classic work, Oliver (1991) asserts that organisations can adopt a range of strategic responses to their environments. For our purposes, two of these are particularly relevant: organisational avoidance and conformity. In this context, neo-institutionalist theories suggest that organisations tend to accept the norms, values, and rules already existing in their environment in order to survive (Gornitzka, 1999). Hence, given the scarcity of incentives to hire foreign academics, it is not surprising that most of universities hire mostly local candidates. Nevertheless, as Oliver (1991) argues, universities which avoid conformity may exist and thus, this possibility should not be excluded. At the same time, the resource dependence theory (Pfeffer, 1982) submits that the greater a HEI's dependency on environmental resources, the higher the likelihood that the organisation will adapt to its social and economic context. In other words, organisations change when not doing so jeopardises the flow of their external resources.

In countries like Spain, only a very small proportion of the university funding system is based on performance and so there is very limited economic incentive for them to compete for talented researchers in the global academic market. Moreover, attracting international academics is also influenced by university-level factors, such as campus facilities and infrastructures, potential for attracting research funds, and institutional reputation (see Lepori et al., 2015 for a complete review of the factors determining academic mobility).

\section{HIRING ACADEMIC STAFF IN SPAIN}

We must also understand how the factors mentioned in the previous section affect the hiring processes in Spanish universities. In terms of university autonomy, Spain's public HEIs only have limited independence in terms of their human resources policy. The selection process for academic civil servants is based on a two-step model $^{2}$. In the first stage candidates must be accredited by a public foundation called ANECA (the Agencia Nacional de Evaluación de la Calidad y Acreditación, translated as the National Agency of Quality Assessment and Accreditation Evaluation). There are two types of accreditations for academic civil servant positions: Profesor Titular (tenured junior professors) and Catedrático (tenured full senior professors). ANECA determines the requirements that candidates must fulfil in order to obtain accreditation (i.e. they establish the evaluation criteria) and also undertake the evaluation of all the candidates (Pereira-Puga, 2016b).

Once a candidate is awarded an accreditation they can apply for open positions at the university level. Thus, universities have some autonomy in their hiring processes in that they make the final decision on which candidate is awarded the position. However, they can only select a candidate that has been previously accredited by ANECA, making it difficult to attract foreign candidates because most international academics do not hold the required accreditation ${ }^{3}$. Moreover, the process of obtaining this accreditation is very bureaucratic and takes several months. Additionally, candidates holding a PhD awarded by a foreign university must get their diploma ratified by the Spanish Administration, another process which takes months or even years and discourages foreign academics from moving to Spain (Grove, 2016). Likewise, although there are some insignificant regional differences, wages in the Spanish higher education system are fixed by law (Cruz-Castro and Sanz-Menéndez, 2015; Pereira-Puga, 2016b). This means that universities cannot negotiate salaries with potential candidates and reduces Spain's competitiveness as a research destination (Pereira-Puga, 2016a).

2 This system was established in 2007 . The process is basically the same as for other types of non-civil servant positions. However, it must be noted that ANECA (see text body) have a series of regional counterparts that are allowed to provide accreditations for non-tenured positions and for tenured positions without civil servant status.

3 Nevertheless, according to the law, foreign candidates can apply for positions without holding an ANECA accreditation, depending on their seniority. 
Regarding the attractiveness of the country, the situation is ambivalent. Spain is part of the EU, thus allowing the free circulation of workers from any member state, and is a member of the European Higher Education Area (EHEA) and the European Research Area (ERA). It also participates in all the European programs devoted to higher education, science, technology and innovation, including the European Commission's frameworks (e.g. Horizon 2020), Erasmus, Erasmus Plus, etc., all of which can bolster Spain's inbound mobility therefore making it more attractive to foreign academics. However, according to the main rankings, no Spanish university has yet achieved a world top 100 ranking (Grau i Vidal, 2013; Grove, 2016), making the country less attractive to outstanding researchers. Similarly, other reasons such as language barriers (Musselin, 2004) may also negatively affect Spain's attractiveness.

Finally, institutional factors including HEIs' responses to change, reputation, infrastructures and facilities, competitiveness in terms of attracting funding, etc. are also very important, and Spanish universities significantly vary in this respect. The Spanish higher education system is the result of a combination of old universities, some of them established in the medieval era (e.g. Complutense University of Madrid, Salamanca, Valencia, and Zaragoza Universities, and the University of Santiago de Compostela, among others), and new institutions, most of which opened in the 1990s. Some of the latter are located in global cities (Sassen, 2002), such as Pompeu Fabra University (Barcelona) and Carlos III University (Madrid), while some others were established in peripheral cities and towns. Therefore, these and other factors account for the significant differences between HEIs.

\section{METHODOLOGY}

This article aims to deepen our understanding of the factors affecting the internationalisation of academic staff in the higher education sector. The analysis is based on data from the European Register of Tertiary Education Institutions (ETER) database, the most comprehensive and up-to-date database on the European higher education sector. ETER is an open-access database sponsored by the European Commission which contains data on students, staff, research activities, funding, etc., from almost 3,000 universities in 36 European countries. Some additional data used for the analysis come from Spain's most current database and reliable source of data on the Spanish higher education sector, the Higher Education Statistics (Estadística de la Enseñanza Universitaria) produced annually by Spain's National Statistics Office.

The data for the total academic and international staff for the 48 Spanish public universities were used to calculate internationalisation ratios: specifically, the percentage of foreign professors (including non-tenured and tenured positions) included in the total academic staff. In addition, the percentage of foreign professors in the 17 Spanish regions and in every Spanish public university was calculated in order to generate macro-level (regional) and micro-level (university) information. Furthermore, details of the Catalonian science system, based on secondary data obtained from different bibliographic and statistical sources, are given in order to outline why many of the most internationalised Spanish universities are located in that region.

\section{RESULTS: INTERNATIONALISATION OF ACADEMIC STAFF} IN SPANISH UNIVERSITIES

Comparisons of the ratios of foreign academic staff in Spanish HEIs should be taken in the context of internationalisation in the European higher education sector. Graph 1 shows the percentage of foreign academic staff in 10 European countries; the Netherlands and the United Kingdom lead the table, with $33.9 \%$ and $27.3 \%$ of staff in their universities being foreign, respectively, whereas Spain has the

4 The graph includes all European countries whose figures on international academic staff are available in the ETER database. The data include both public and private universities. 
Graph 1. Percentage of international academic staff in European universities (2013)

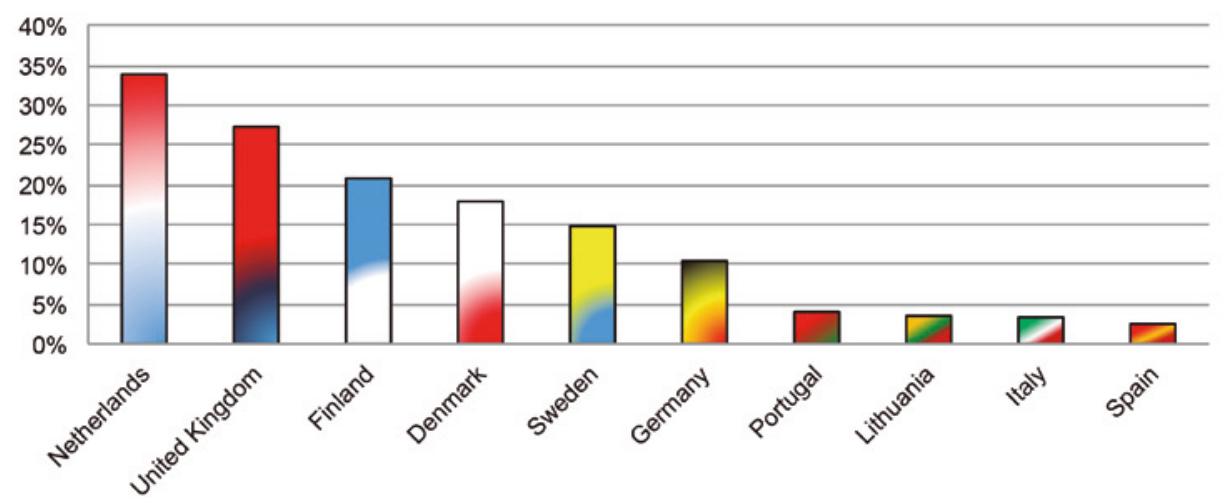

SOURCE: Author's own elaboration from data from the ETER database

lowest levels of internationalisation of any country in the sample at $2.5 \%$. In other words, the Spanish higher education system is not competitive in the context of the global academic market.

Focusing on Spain, Graph 2 shows the share of foreign academic staff present in public universities, organised by region. Here, we can see significant differences between autonomous communities, although the ratios of foreign staff present were low in every region. According to the data, the most internationalised region is Catalonia (where $4.7 \%$ of academic staff are foreign), followed at some distance by the Canary Islands (2.9\%), the Balearic Islands (2.6\%), and Madrid (2.6\%). In contrast, there are four communities in which the percentage of foreign academic staff does not even reach one percent: La Rioja (0.5\%), Navarra (0.8\%), Castile and León (0.9\%), and Aragon (0.95\%). These numbers indicate that openness in terms of recruiting foreign academic staff is poor in these regions. Additionally, it is surprising that some of the most economically developed autonomous communities, such as Navarra, the Basque Country, and the Valencian Community do not seem to have adopted successful internationalisation strategies.

Moving from the regional to the institutional level, Graph 3 shows the percentage of international staff present in Spanish public universities. Firstly, four out of the five most internationalised universities are located in the same region: Catalonia. In addition, most of the Catalan HEIs performed above the Spanish average $(2.2 \%)$. Here, it is important to remember that Spain is one of the most decentralised countries in Europe: Spain's regions have a wide degree of autonomy in areas such as educational policy and autonomous governments are responsible for every level of education (from primary to tertiary), even though central government still maintains power in terms of some key legislative issues (Puelles, 2002; Bonal, 2005).

In this sense, Catalonia is an interesting case study. Located on the Mediterranean coast of Spain, Catalonia is the country's second most populated region (with some 7.5 million inhabitants in $2016^{\mathbf{5}}$ ) and the largest in terms of its foreign population (accounting for 1.0 million inhabitants in 20146). Its GDP per capita in terms of purchasing power standards is the highest in the Country, making it one of the most developed regions in Southern

5 Source: Spanish Statistics Office: http://ine.es/jaxiT3/ Tabla.htm?t=2853\&L=0

6 Source: Spanish Statistics Office: http://www.ine.es/jaxi/ Tabla.htm?path=/t20/e245/p04/provi/l0/\&file=0ccaa002. $p \times \& L=0$ 
Graph 2. Percentage of international academic staff in Spanish public universities by region (2013)

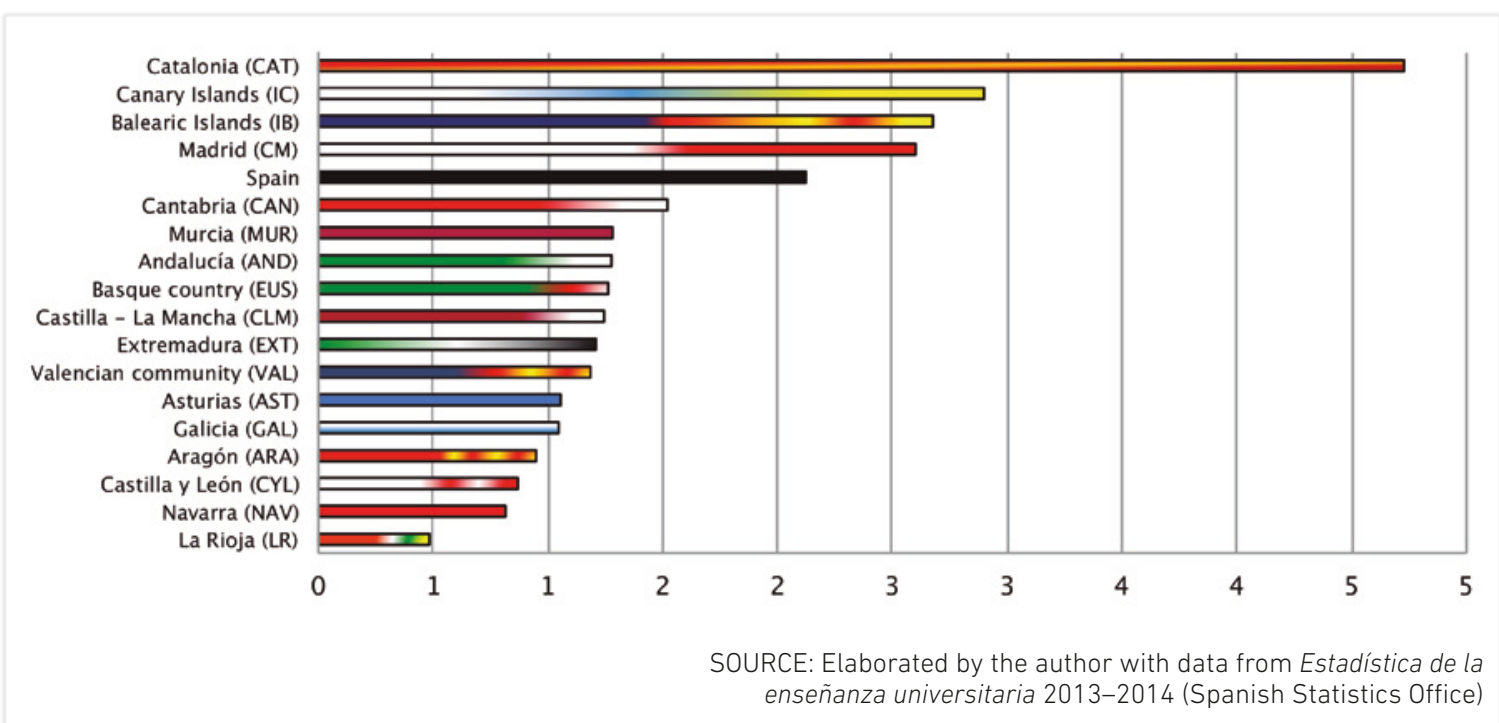

Europe $^{7}$. The Catalan government has also used its authority to promote research excellence, especially in science. One of its most notable initiatives was the establishment of the Catalan Institution for Research and Advanced Studies (abbreviated as ICREA in Spain). This foundation, supported by the Catalan government, aims to hire and retain world leading-researchers. ICREA hires outstanding academics in order to fill positions in Catalan universities and research centres and offers salaries much higher than those fixed by the Spanish law, markedly improving the attractiveness of Catalonia as a research destination. There are currently 258 ICREA research professors (from 28 different countries) and these represent $1.5 \%$ of all academics in Catalonia. ICREA members have attracted 288 million euros in research funds over the last five years and it is estimated that each fellow has maintained an average 6.5 full-time academic jobs (for more information on ICREA see its 2016 Annual Report).

7 Eurostat Regional Yearbook 2016: http://ec.europa.eu/ eurostat/statistical-atlas/gis/viewer/?year $=\&$ chapter $=$ 06 \& mids $=2,52 \& 0=1,1$ \&center $=50.36441,15.65899,3 \&$ nu $\mathrm{ts} / \mathrm{d}=\mathrm{ES} 51 \&$
Along with the establishment of ICREA, the Catalan government also promoted the creation of excellence research centres (such as the Institute of Chemical Research of Catalonia, the Institute for Research in Biomedicine, the Centre for Genomic Regulation, and the Institute of Photonic Sciences) which play a very relevant role in attracting research funds as well as in hiring and retaining outstanding researchers. Additionally, the Catalan government has challenged the Spanish traditional scheme of professorships based on civil servant positions by creating non-civil servant full professorships (Catedràtic contractat ${ }^{\mathbf{8}}$ ), which aim to make the human resources structure more flexible.

The antithesis of the Catalan case is Andalusia. Both regions are similar in terms of population and the number of public universities. However, as shown in Graph 3, only one of the Andalusian universities has an above-Spanish average number of foreign academics (Pablo de Olavide University). Madrid falls intermediate between these two cases: there are six public universities in the region, three of

8 For more details on academic careers in Catalonia see: http://www.aqu.cat/doc/doc_45839814_1.pdf 
Graph 3. Percentage of international academic staff by university (2013)*

Pompeu Fabra university (CAT)

Carlos III University of Madrid (CM)

Autonomous University of Barcelona (CAT)

Technical University of Catalunya (CAT) University of Girona (CAT)

University of La Laguna (IC)

Rey Juan Carlos University (CM)

Rovira i Virgili University (CAT)

Autonomous University of Madrid (CM)

Pablo de Olavide University (AND)

University of Barcelona (CAT)

University of Balearic Islands (IB)

Spain

University of Alicante (VAL)

University of Granada (AND)

Complutense University of Madrid (CM)

University of Sevilla (AND)

University of Las Palmas de Gran Canaria (IC)

University of Cantabria (CAN)

University of Salamanca (CYL)

Technical University of Madrid (CM)

University of Murcia (MUR)

University of Vigo (GAL)

University of Basque Country (EUS)

University of Castilla-La Mancha (CLM)

Technical University of Valencia (VAL)

University of Extremadura (EXT)

University of A Coruña (GAL)

Technical University of Cartagena (MUR)

Jaume I University (VAL)

University of Oviedo (AST)

University of Valencia (VAL)

University of Zaragoza (ARA)

University of León (CYL)

University of Lleida (CAT)

University of Córdoba (AND)

Public University of Navarra (NAV)

University of Málaga (AND)

University of Cádiz (AND)

University of Santiago de Compostela (GAL)

University of Alcalá (CM)

Miguel Hernández University of Elche (CV)

University of Valladolid (CyL)

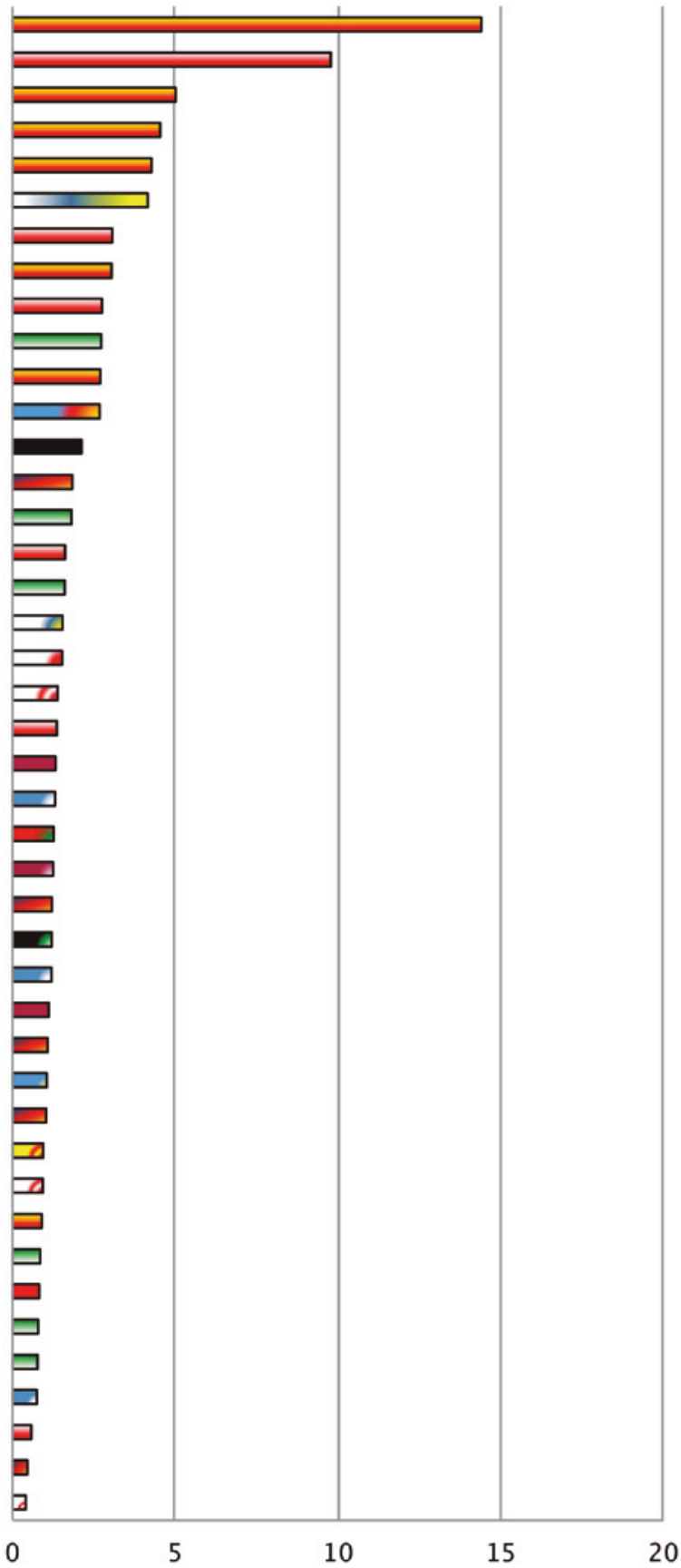

SOURCE: Author's own elaboration from data from the ETER database

* No data were available for the universities of Almería, Burgos, Huelva, Jaén, or La Rioja. 
them ranked in the top 10 (Carlos III, Rey Juan Carlos, and the Autonomous University), while two others are in the middle of the table, and one is at the bottom (Graph 3). Interestingly, 8 out of 17 Spanish autonomous communities have only a public university (Aragon, Asturias, the Balearic Islands, the Basque Country, Cantabria, Castile La Mancha, La Rioja, and Navarra). Graph 3 illustrates that all these universities performed below the Spanish average, with the exception of the University of the Balearic Islands.

Previously published work (Pereira-Puga, 2015) showed that there is generally very little competition between Spanish universities to attract students, staff, and funding. Indeed, their resources come mainly from public sources and the funding system is only cursively based on performance. Around $90 \%$ of their students are from their own region and in many of them the ratios of inbred academics are exceptionally high. Thus, a hypothesis for future research is that low levels of competition between universities discourages the recruitment of external candidates. Lastly, the vast majority of institutions that rank highly in the ratio tables presented here are newly-created universities. One might expect that older HEIs would be more attractive to foreign researchers because of their history and reputation. However, in the Spanish case it seems that new ideas and styles of leadership in younger institutions are helping to attract foreign talent.

In summary, this data highlights the fact that the ratio of foreign academics in Spanish HEIs is very low. This is probably related to the bureaucracy of the current national system of hiring and promotion, based on accreditations awarded by ANECA and its regional counterparts, which discourages international candidates from applying for positions. Additionally, academic salaries in Spain are fixed by law and are not competitive compared to those in other European countries. Regarding the attractiveness of the country, the fact that some universities have very few foreign professors shows that Spanish HEIs are not maximising Spain's potential academic attractiveness (as an EU member state, active participant in the
EHEA, and ERA, etc.) to boost recruitment of talented foreign researchers. Finally, the large differences found between universities located in the same region indicates that attracting outstanding researchers is not only related to external aspects (central government laws, regional policies, etc.), but that it is also related to universities' willingness to participate in the global higher education market.

\section{CONCLUSIONS}

The university sector has considerably changed over the past four decades and one of the major changes has been the process of internationalisation. Among other requirements, academics are now expected to raise funds from international funding bodies, to take part in international research projects, and to co-author academic work with foreign colleagues. Research into the internationalisation of the higher education sector has highlighted the existence of a global human resources market, where universities compete to hire outstanding academics. However, this global market only involves a few countries and institutions, while most national human resources markets remain local. In this context, this article analyses the Spanish case in order to deepen our understanding on the factors influencing hiring-process outcomes in terms of international university staff.

The data presented here shows that Spain is not a competitor in the global academic human resources market. Indeed, the proportion of foreign academic staff working in Spanish universities is much lower than that in other European countries including the Netherlands, the United Kingdom, Finland, Denmark, Sweden, and Germany ${ }^{9}$. However, there are significant differences between individual Spanish regions. At the institutional level, the most internationalised universities are young institutions (aged less than

9 The percentages of foreign academic staff at the national level include both public and private universities but at the regional and institutional level they include only public universities. 
100 years) and most of them are located in Catalonia. Additionally, there are significant differences between universities located in the same region: HEIs belonging to the same autonomous community perform dissimilarly in terms of attracting foreign academics.

Spain is an interesting case example for explaining how environmental (normative frameworks, funding systems, wages, bureaucracies, etc.) influence university hiring-process decisions. Nevertheless, the differences found between universities (even between universities located in the same region) show that HEIs are not passive players. They are able to make decisions either to increase their share of foreign professors or to hire mainly local staff. Additionally, this article also briefly discusses the Catalonian case-the most internationalised region in Spain. Taking advantage of its autonomy, the Catalonian regional government has established a range of policies aimed at increasing the internationalisation of its universities. Some examples of this are the creation of non-civil servant professorships, the implementation of more flexible hiring procedures, and the establishment of the ICREA foundation. These initiatives show that, in decentralised countries, regional polices may generate a significant change in universities' degree of openness and internationalisation.

Although this work highlights some interesting points, it is an exploratory study and so further research should be carried out in this area, both to quantify the effects of different factors on universities' hiring-processes decisions and to improve our knowledge of the institutional factors (e.g. leadership, organisational structures, etc.) that determine universities' degree of participation in the global higher education market.

\section{REFERENCES}

Altbach, P. (2015). Perspectives on internationalizing higher education. International Higher Education, 27, 6-8.

Altbach, P. G., Reisberg, L., and Rumbley, L. E. (2009). Trends in global higher education: Tracking an academic revolution. Paris: UNESCO.

Altbach, P., and Teichler, U. (2001). Internationalization and exchanges in a globalized university. Journal of Studies in International Education, 5(1), 5-25.

Bauder, H. (2015). The international mobility of academics: A labor market perspective. International Migration, 53(1), 83-96.

Bonal, X. (2005). La descentralización educativa en España: Una mirada comparativa a los sistemas escolares de las comunidades autónomas. Barcelona: Fundació Carles Pi i Sunyer.

Bosch, X. (2006). Spain reconsiders its university reform law. Science, 314(5801), 911.

Byram, M., and Dervin, F. (2009). Students, staff and academic mobility in higher education. Newcastle: Cambridge Scholars Publishing.

Cruz-Castro, L., and Sanz-Menéndez, L. (2015). Policy change and differentiated integration: Implementing Spanish higher education reforms. Journal of Contemporary European Research, 11(1), 103-123.

De Jong, G.F., and Fawcett, J.T. (1981). Motivations for migration: An assessment and a value-expectancy research model. In G. F. De Jong, and R. W. Gardner (ed.), Migration decision making: multidisciplinary approaches to microlevel studies in developed and developing countries. New York: Pergamon.

De Wit, H. (2002). Internationalization of higher education in the United States of America and Europe: A historical, comparative, and conceptual analysis. Westport, CT: Greenwood Publishers.

Dobbins, M., and Knill, C. (2009). Higher education policies in Central and Eastern Europe: Convergence towards a common model? Governance, 22(3), 397-430.

Enders, J. (2014). The Academic arms race: International rankings and global competition for World-class universities. In A. M. Pettigrew, E. Cornuel, and U. Hommel, U. (ed.), The institutional development of business schools (p. 155-175). Oxford: Oxford University Press. 
Enders, J. (2004). Higher education, internationalization, and the nation-state: Recent developments and challenges to governance theory. Higher education, 47(3), 361-382.

Godechot, O., and Louvet, A. (2008). Academic inbreeding: An evaluation. Laviedesidees, fr, 22. Accessed on the 13th of May 2017 at http://www.booksandideas.net/Academic-Inbreeding-An-Evaluation.html

Gornitzka, Å. (1999). Governmental policies and organisational change in higher education. Higher education, $38(1), 5-31$.

Grant, R. (1996). Toward a Knowledge-Based Theory of the Firm. Strategic Management Journal, 17 (Winter), $109-122$.

Grau i Vidal, X. (2013). El 'ranking' de Shanghái: excelencia y especialización. El País. Accessed on the 14th of May 2017 at http://sociedad.elpais.com/sociedad/2013/08/30/actualidad/1377888296_646844.html

Griffith, R. (1993). Budget cuts and shared governance: An administrator's perspective. Academe, 79(6), 15-17.

Grove, L. (2016). Barcelona rises above Spain's higher education malaise. Times Higher Education. Accessed on the 14th of May 2017 at https://www.timeshighereducation.com/news/barcelona-rises-above-spains-higher-education-malaise

Hazelkorn, E. (2011). Globalization and the reputation race in rankings and the reshaping of higher education: the battle for World-class excellence. London: Palgrave MacMillan.

ICREA. (2017). ICREA 2016 Memoir. Accessed on the 16th of May 2017 at http://memoir.icrea.cat/wp-content/ uploads/2017/05/desplegable-ICREA.pdf

Jongbloed, B., and Vossensteyn, H. (2001). Keeping up performances: an international survey of performance-based funding in higher education. Journal of Higher Education Policy and Management, 23(2), 127-145.

Kerr, C. (1993). Universal issues in the management of higher education. In J. B. Balderston, and F. Balderston (ed.), Higher education in Indonesia: Education and reform. Berkeley: Center for Studies in Higher Education.

Kim, T., and Locke, W. (2010). Transnational academic mobility and the academic profession. London: Centre for Higher Education Research and Information, The Open University.

Lepori, B., Seeber, M., and Bonaccorsi, A. (2015). Competition for talent. Country and organizational-level effects in the internationalization of European higher education institutions. Research Policy, 44(3), 789-802.

Liefner, I. (2003). Funding, resource allocation, and performance in higher education systems. Higher education, 46(4), 469-489.

Mazzarol, T., amd Soutar, G. N. (2012). Revisiting the global market for higher education. Asia Pacific Journal of Marketing and Logistics, 24(5), 717-737.

Mazzarol, T., and Soutar, G. N. (2001). The global market for higher education: Sustainable Competitive Strategies for the New Millennium. Northampton, MA: Edward Elgar.

McLendon, M. K., and Hearn, J. C. (2013). The resurgent interest in performance-based funding for higher education. Academe, 99(6), 25.

Musselin, C. (2004). Towards a European academic labour market? Some lessons drawn from empirical studies on academic mobility. Higher Education, 48(1), 55-78.

OCDE (2008). The Global Competition for Talent. Mobility of the Highly Skilled. Paris: OCDE.

OCDE (1996). The Knowledge based Economy. Paris: OCDE.

Oliver, C. (1991). Strategic responses to institutional processes. The academy of management review, 16(1), 145-179.

Olsen, J. (2007). The institutional dynamics of the European University. In M. Peter, and J. Olsen (ed.), University Dynamics and European Integration (p. 25-54). Dordrecht: Springer.

Pereira-Puga, M. (2016a). ¿Cuánto talento atrae la Universidad Española?, Agenda Pública. Accessed on the 13th of May 2017 at http://agendapublica.elperiodico.com/cuanto-talento-atrae-la-universidad-espanola/

Pereira-Puga, M. (2016b). ¿En qué se parecen la endogamia académica y las patatas fritas?, Agenda Pública. Accessed on the 13th of May 2017 at http://agendapublica.elperiodico.com/en-que-se-parecen-la-endogamia-academi ca-y-las-patatas-fritas/

Pereira-Puga, M. (2015). España en el mercado de educación superior: universalización de la enseñanza universitaria y atracción de alumnado. RIESED-Revista Internacional de Estudios sobre Sistemas Educativos, 2(5), 01-16.

Pereira-Puga, M. (2014). Educación superior universitaria: calidad percibida y satisfacción de los egresados. PhD Thesis. Universidade da Coruña, La Coruña. 
Peterson (2007). The Study of Colleges and Universities as Social Organizations. In P. J. Gumport (ed.), Sociology of Higher Education: Contributions and their Contexts. Baltimore: The Johns Hopkins University Press.

Pfeffer, J. (1982). Organizations and Organization Theory. Boston: Pitman.

Puelles, M. (2002). Descentralización de la educación en el estado autonómico. In Informe España 2002: Una interpretación de su realidad social (p. 143-241). Madrid: Fundación Encuentro.

Ritsilä, J., and Ovaskainen, M. (2001). Migration and regional centralization of human capital. Applied Economics, 33(3), 317-325.

Salmi, J. (2009). The challenge of establishing world-class universities. Washington: World Bank Publications.

Sassen, S. (2002). Global networks, linked cities. New York: Routledge.

Scott, P. (1998). The Globalization of Higher Education. Buckingham: Open University Press and the Society for Research into Higher Education.

Sivak, Y., and Yudkevich, M. (2009). Academic inbreeding: pro and contra. Educational Studies, 1, $170-187$.

Wang, Q., Cheng, Y., and Liu, N. C. (2013). Building world-class universities: Different approaches to a shared goal. Berlin: Springer Science and Business Media.

Whitley, R. (2012). Transforming universities: National conditions and their varied organisational actorhood. Minerva, 50(4): 493-510.

Yudkevich, M., Altbach, P., and Rumbley, L. E. (2015). Academic inbreeding and mobility in higher education: Global perspectives. Berlin: Springer.

\section{BIOGRAPHICAL NOTE}

Manuel Pereira-Puga has a doctorate in Sociology from the University of A Coruña. His research interests include higher education and science systems and policies, as well as the relationships between science, technology, and society. 